\title{
Antioxidant activity of the methanol extract of Ferula assafoetida and its essential oil composition
}

\author{
By Abbas Ali Dehpour, ${ }^{a}$ Mohammad Ali Ebrahimzadeh, ${ }^{\text {b* }}$ \\ Nabavi Seyed Fazel, ${ }^{b}$ and Nabavi Seyed Mohammad ${ }^{b}$
}

\author{
${ }^{a}$ Department of biology, Islamic Azad University, Qaemshahr, Iran. \\ ${ }^{b}$ Pharmaceutical Sciences Research Center, School of Pharmacy, \\ Mazandaran University of Medical Sciences, Sari, Iran. \\ ( ${ }^{\star}$ Corresponding author: zadeh20@yahoo.com)
}

\section{RESUMEN}

Actividad antioxidante de extractos metanólicos de Ferula assafoetida y la composición de su aceite esencial.

La actividad antioxidante de las partes aéreas de $\mathrm{Fe}$ rula assafoetida se determinó empleando varios sistemas de ensayos in vitro. EI IC ${ }_{50}$ de la actividad captadora de radicales de DPPH fue $380 \pm 12 \mathrm{mg} \mathrm{ml}^{-1}$. Los extractos también mostraron una buena actividad captadora de óxido nítrico $\left(\mathrm{IC}_{50}\right.$ fue $\left.270 \pm 3\right)$ y capacidad quelatante de $\mathrm{Fe}^{2+}$ $\left(\mathrm{IC}_{50}\right.$ fue $\left.0.57 \pm 0.02 \mathrm{mg} \mathrm{ml}^{-1}\right)$. La inhibición de la peroxidación (actividad antioxidante) de los extractos mostró valores del $82 \%$ (a las 24 horas) y $88 \%$ (a las 72 horas). El extracto mostró un ligero descenso del poder reductor con 25- $800 \mu \mathrm{g} \mathrm{ml}^{-1}$ de extracto que no fue comparable con la vitamina $C(p<0.001)$. Los extractos ensayados mostraron una muy baja actividad antioxidante. Además, la composición química del aceite esencial de las partes aéreas fue determinada. Los principales compuestos fueron fenol, 2-metil-5-(1-metil etilo) (18.2\%), $\alpha$-Bisabolol (10.4\%) and Arsine trietilo $(8.7 \%)$. Los fenoles totales, determinados por el método de Folin-Ciocalteau, fue de $94.8 \pm 5.9 \mathrm{mg}$ de equivalentes de ácido gálico/g de extracto en polvo y el contenido total de flavonoides (por el método del $\mathrm{AlCl}_{3}$ ) fue de $90.9 \pm 6.3 \mathrm{mg}$ de equivalentes de quercitina/g de extracto en polvo.

PALABRAS CLAVE: Aceite esencial - Actividad antioxidante - Capacidad quelatante - DPPH - Ferula assafoetida.

\section{SUMMARY}

Antioxidant activity of the methanol extract of Ferula assafoetida and its essential oil composition.

The antioxidant activity of the aerial parts of Ferula assafoetida was determined by employing various in vitro assay systems. $\mathrm{IC}_{50}$ for DPPH radical-scavenging activity was $380 \pm 12 \mathrm{mg} \mathrm{ml}^{-1}$. The extracts showed good nitric oxide-scavenging activity $\left(\mathrm{IC}_{50}\right.$ was $\left.270 \pm 3\right)$ and $\mathrm{Fe}^{2+}$ chelating ability $\left(\mathrm{IC}_{50}\right.$ was $\left.0.57 \pm 0.02 \mathrm{mg} \mathrm{ml}^{-1}\right)$. The peroxidation inhibition (antioxidant activity) of the extracts exhibited values from $82 \%$ (at $24 \mathrm{hrs}$ ) and $88 \%$ (at $72 \mathrm{hrs}$ ). The extract exhibited a fairy weak reducing power at 25-800 $\mu \mathrm{g} \mathrm{ml}^{-1}$ of extracts which was not comparable with Vitamin C $(p<0.001)$. The tested extracts exhibited very low antioxidant activity. In addition, the chemical composition of the essential oil of the aerial parts was determined. The major compounds were phenol, 2-methyl-5-(1-methyl ethyl)
(18.2 \%), $\alpha$. -Bisabolol (10.4\%) and Arsine triethyl (8.7\%). Total phenol compounds, as determined by the Folin Ciocalteu method, were $94.8 \pm 5.9 \mathrm{mg}$ gallic acid equivalent/g of extract powder and the total flavonoid content (by $\mathrm{AlCl}_{3}$ method) was $90.9 \pm 6.3 \mathrm{mg}$ quercetin equivalent $/ \mathrm{g}$ of extract powder.

KEY-WORDS: Antioxidant activity - Chelating ability $D P P H$ - Essential oil - Ferula assafoetida.

\section{INTRODUCTION}

The role of free radicals in many disease conditions has been well established. Several biochemical reactions in our body generate reactive oxygen species and these are capable of damaging crucial bio-molecules. If they are not effectively scavenged by cellular constituents, they lead to disease conditions (Halliwell et al. 1992). The harmful action of free radicals can be blocked by antioxidant substances, which scavenge the free radicals and detoxify the organism. Several plant extracts and different classes of phytochemicals have been shown to have antioxidant activity (Cao et al. 1996; Wang et al. 1996; Zheng and Wang 2001). The search for newer natural antioxidants, especially of plant origin, has been increasing ever since. Plants have been a constant source of drugs and recently, much emphasis has been placed on finding new therapeutic agents from medicinal plants. Today many people prefer to use medicinal plants rather than chemical drugs.

The Ferula genus from the family of Umbelliferae has been found to be a rich source of gum-resin (Fernch 1971). This resin enjoys a reputation as a folklore medicine (Abd El-Razek et al. 2001). It is considered to be a sedative, carminative, antispasmodic digestive, expectorant, laxative, analgesic, anthelminitic, antiseptic and a diuretic in its properties. It is also believed to have aphrodisiac properties and increase sexual appetite (Eigner and Scholz 1990). This genus presents interesting phytochemical features, such as the occurrence of sesquiterpenes and sesquiterpene coumarins (Abd El-Razek et al. 2001; Kojima et al. 
2000; Su et al. 2000). F. assafoetida L. is an herbaceous wild plant native to Iran. It is herbaceous and perennial and grows up to $2 \mathrm{~m}$ high. In Iranian traditional medicine, F. assafoetida gum extract has been used as a remedy for abdominal pain, constipation and diarrhea and as an antihelminthic (Fatehi et al. 2004). Although there is some evidence for the anticoagulant action (Leung 1980), antispasmodic and hypotensive effects of F. assafoetida gum (Fatehi et al. 2004) and pregnancy interceptive activity (Keshri et al. 2004). The essential oil composition of this plant has been published recently (Khajeh et al. 2005). In this study, the essential oil composition and antioxidant activity of the Ferula assafoetida aerial parts were examined by employing various in vitro assay systems, such as DPPH and nitric oxide radical scavenging, reducing power, linoleic acid and iron ion chelating power, in order to understand the usefulness of this plant.

\section{MATERIALS AND METHODS}

\subsection{Plant materials}

The aerial parts of Ferula assafoetida were collected from Sari forest, Iran, in the summer of 2007. After identification of the plant by Dr. Bahman Eslami, a voucher (No. 340) has been deposited in the Sari School of Pharmacy herbarium.

\subsection{Chemicals}

Ferrozine, Linoleic acid, trichloroacetic acid (TCA), 1,1-diphenyl-2-picryl hydrazyl (DPPH) and potassium ferricyanide were purchased from Sigma Chemicals Co. (USA). Butylated hydroxyanisole (BHA), ascorbic acid, sulfanilamide, N-(1-naphthyl) ethylenediamine dihydrochloride, hydrogen peroxide, ethylenediaminetetraacetic acid (EDTA) and Ferric chloride were purchased from Merck (Germany). All other chemicals were of analytical grade or more pure.

\subsection{Isolation of the essential oil}

The air-dried and ground aerial parts of the plant collected were submitted for $3 \mathrm{~h}$ to water-distillation using a British-type Clevenger apparatus. The obtained essential oil was dried over anhydrous sodium sulphate and after filtration, stored at $4^{\circ} \mathrm{C}$ until tested and analyzed.

\subsection{Gas Chromatography-Mass Spectrometry (GC-MS)}

GC-MS was carried out using a HewlettPackard 5975B series instrument and an Agilent 19091J-433 HP-5 capillary column (30 m., $250 \mu \mathrm{m}$ i.d., film thickness $0.25 \mu \mathrm{m}$ ) which was set at $50^{\circ} \mathrm{C}$ for $10 \mathrm{~min}$, then increased $4^{\circ} \mathrm{C} / \mathrm{min}$ to $300^{\circ} \mathrm{C}$; using helium as a carrier gas at a flow rate of $1 \mathrm{ml} / \mathrm{min}$. The split ratio was 1:10; ionization energy was 70 eV; scan time was $1 \mathrm{~s}$; acquisition mass range was $\mathrm{m} / \mathrm{z}$ 40-400. The compounds were identified according to their retention indexes and by comparison of their mass spectra with those of a computer library or with authentic compounds. apinene, Decane, Benzene and Limonene were identified by co-injection.

\subsection{Preparation of methanolic extract}

The aerial parts were dried at room temperature and coarsely ground before extraction. A known amount of each part was extracted at room temperature following the percolation method using methanol. The resulting extract was concentrated over a rotary vacuum until a crude solid extract was obtained $(10.8 \%)$, which was then freeze-dried for complete solvent removal.

\subsection{Determination of total phenolic compounds and flavonoid content}

Total phenolic compound contents were determined by the Folin-Ciocalteau method (Ebrahimzadeh et al. 2008a,b). The extract sample $(0.5 \mathrm{ml})$ was mixed with $2.5 \mathrm{ml}$ of a $0.2 \mathrm{~N}$ Folin-Ciocalteau reagent for $5 \mathrm{~min}$ and then $2.0 \mathrm{ml}$ of $75 \mathrm{~g} \mathrm{I}^{-1}$ sodium carbonate were added. The absorbance of the reaction was measured at 760 $\mathrm{nm}$ after $2 \mathrm{~h}$ of incubation at room temperature. Results were expressed as gallic acid equivalents. Total flavonoids were estimated using the method of Ordonez et al. (Ebrahimzadeh et al. $2008 \mathrm{a}, \mathrm{b})$. Briefly, $0.5 \mathrm{~mL}$ solution of plant extract in methanol were separately mixed with $1.5 \mathrm{~mL}$ of methanol, $0.1 \mathrm{~mL}$ of $10 \%$ aluminum chloride, 0.1 $\mathrm{mL}$ of $1 \mathrm{M}$ potassium acetate, and $2.8 \mathrm{~mL}$ of distilled water and left at room temperature for 30 minutes. The absorbance of the reaction mixture was measured at $415 \mathrm{~nm}$ with a double beam spectrophotometer (Perkin Elmer). The total flavonoid contents were calculated as quercetin from a calibration curve.

\subsection{DPPH radical-scavenging activity}

The stable 1,1-diphenyl-2-picryl hydrazyl radical (DPPH) was used for the determination of the free radical-scavenging activity of the extracts (Ebrahimzadeh et al. 2008a,b; Nabavi et al. $2008 a, b)$. Different concentrations of extract were added, at an equal volume, to a methanolic solution of DPPH (100 mM). After $15 \mathrm{~min}$ at room temperature, the absorbance was recorded at 517 $\mathrm{nm}$. The experiment was repeated three times. Vitamin C, BHA and quercetin were used as standard controls. $I_{50}$ values denote the concentration of the sample, which is required to scavenge $50 \%$ of DPPH free radicals. 


\subsection{Reducing power determination}

The reducing power of $F$. assafoetida was determined according to the method of Yen and Chen (Ebrahimzadeh et al. 2008a,b; Nabavi et al. $2008 \mathrm{a}, \mathrm{b}) .2 .5 \mathrm{ml}$ of extract $\left(25-800 \mathrm{mgml}^{-1}\right)$ in water were mixed with a phosphate buffer $(2.5 \mathrm{ml}, 0.2 \mathrm{M}$, $\mathrm{pH} 6.6)$ and potassium ferricyanide $\left[\mathrm{K}_{3} \mathrm{Fe}(\mathrm{CN})_{6}\right](2.5$ $\mathrm{ml}, 1 \%$ ). The mixture was incubated at $50^{\circ} \mathrm{C}$ for 20 min. A portion $(2.5 \mathrm{ml})$ of trichloroacetic acid $(10 \%)$ was added to the mixture to stop the reaction, which was then centrifuged at $3000 \mathrm{rpm}$ for $10 \mathrm{~min}$. The upper layer of the solution $(2.5 \mathrm{ml})$ was mixed with distilled water $(2.5 \mathrm{ml})$ and $\mathrm{FeCl}_{3}(0.5 \mathrm{ml}, 0.1 \%)$, and the absorbance was measured at $700 \mathrm{~nm}$. Increased absorbance of the reaction mixture indicated increased reducing power. Vitamin $\mathrm{C}$ was used as a positive control.

\subsection{Assay of nitric oxide-scavenging activity}

For the experiment, sodium nitroprusside (10 $\mathrm{mM}$ ), in a phosphate-buffered saline, was mixed with different concentrations of each extract dissolved in water and incubated at room temperature for $150 \mathrm{~min}$. The same reaction mixture, without extract but with an equivalent amount of water, served as the control. After the incubation period, $0.5 \mathrm{ml}$ of Griess reagent was added. The absorbance of the chromophore formed was read at $546 \mathrm{~nm}$. Quercetin was used as a positive control (Ebrahimzadeh et al. 2008a,b; Nabavi et al. 2008a).

\subsection{Metal chelating activity}

The chelating of ferrous ions by $F$. assafoetida was estimated according to the method of Dinis et al., (Ebrahimzadeh et al. 2008c). Briefly, the extract $(0.2-3.2 \mathrm{mg} / \mathrm{ml})$ was added to a solution of $2 \mathrm{mM}$ $\mathrm{FeCl}_{2}(0.05 \mathrm{ml})$. The reaction was initiated by the addition of $5 \mathrm{mM}$ ferrozine $(0.2 \mathrm{ml})$, the mixture was shaken vigorously and left standing at room temperature for $10 \mathrm{~min}$. The absorbance of the solution was then measured spectrophotometrically at $562 \mathrm{~nm}$. The percentage inhibition of ferrozine$\mathrm{Fe}^{2+}$ complex formation was calculated as $\left[\left(\mathrm{A}_{0}-\right.\right.$ $\left.\left.A_{s}\right) / A_{s}\right] \times 100$, where $A_{0}$ was the absorbance of the control, and $A_{s}$ was the absorbance of the extract/ standard. $\mathrm{Na}_{2}$ EDTA was used as a positive control.

\subsection{Determination of Antioxidant Activity by the FTC Method}

This method was adopted from Osawa and Namiki (Ebrahimzadeh et al. 2008 a,b; Nabavi et al. 2008a). Twenty $\mathrm{mg} / \mathrm{mL}$ of sample dissolved in $4 \mathrm{~mL}$ of $95 \%(\mathrm{w} / \mathrm{v})$ ethanol were mixed with linoleic acid $(2.51 \%, \mathrm{v} / \mathrm{v})$ in $99.5 \%(\mathrm{w} / \mathrm{v})$ ethanol $(4.1 \mathrm{~mL}), 0.05 \mathrm{M}$ phosphate buffer $\mathrm{pH} 7.0$ (8 $\mathrm{mL})$ and distilled water $(3.9 \mathrm{~mL})$ and kept in screwcap containers at $40^{\circ} \mathrm{C}$ in the dark. $9.7 \mathrm{~mL}$ of $75 \%(\mathrm{v} / \mathrm{v})$ ethanol and $0.1 \mathrm{~mL}$ of
$30 \%(\mathrm{w} / \mathrm{v})$ ammonium thiocyanate were then added to $0.1 \mathrm{~mL}$ of this solution. Precisely $3 \mathrm{~min}$ after the addition of $0.1 \mathrm{~mL}$ of $20 \mathrm{mM}$ ferrous chloride in $3.5 \%$ $(\mathrm{v} / \mathrm{v})$ hydrochloric acid to the reaction mixture, the absorbance at $500 \mathrm{~nm}$ of the resulting red solution was measured; and it was measured again every 24 $\mathrm{h}$ until the day when the absorbance of the control reached its maximum value. The percent inhibition of linoleic acid peroxidation was calculated as: (\%) inhibition $=100-[$ (absorbance increase of the sample/absorbance increase of the control) $\times 100]$. All tests were run in duplicate and analyses of all samples were run in triplicate and averaged. Vit $\mathrm{C}$ and $\mathrm{BHA}$ were used as positive controls.

\subsection{Statistical analysis}

The experimental results are expressed as means \pm SD. All measurements were taken in triplicicate. The data were analyzed by an analysis of variance $(p<0.05)$ and the means separated by Duncan's multiple range tests. The $\mathrm{EC}_{50}$ values were calculated from a linear regression analysis.

\section{RESULTS}

\subsection{Chemical composition of the essential oil}

The results obtained by the GC-MS analysis of the essential oil of the $F$. assafoetida aerial parts are presented in Table 1. Sixty one compounds were identified, representing $98.8 \%$ of the total oil. The oil yield of the plant was determined as $0.94 \% \mathrm{v} / \mathrm{w}$. As determined from the GC-MS analysis, the major compounds were Phenol, 2-methyl-5-(1-methyl ethyl) (18.2\%). Additionally, other major compounds were $\alpha$-Bisabolol (10.4\%), Arsine triethyl (8.7\%) and Cyclopropa [a] naphthaleneoctahydro-tetramethyl (6.6\%).

\subsection{Total phenol and flavonoid contents}

The total phenolic content was $94.8 \pm 5.9 \mathrm{mg}$ gallic acid equivalent/g of extract powder in reference to the standard curve $\left(y=0.0063 x, r^{2}=\right.$ $0.987)$. The total flavonoid content was $90.9 \pm 6.3$ $\mathrm{mg}$ quercetin equivalent/g of extract powder, in reference to the standard curve $(y=0.0067 x+$ $\left.0.0132, r^{2}=0.999\right)$.

\subsection{DPPH radical-scavenging activity}

$\mathrm{IC}_{50}$ for DPPH radical-scavenging activity was $380 \pm 12 \mathrm{mg} \mathrm{ml}^{-1}$. The $\mathrm{IC}_{50}$ values for Ascorbic acid, quercetin and BHA were $1.26 \pm 0.11,1.32 \pm$ 0.07 and $13.49 \pm 1.04 \mathrm{mg} \mathrm{ml}^{-1}$, respectively.

\subsection{Reducing power of extract}

Figure 1 shows the dose- response curves for the reducing powers of the extracts from $F$. 
Table 1

Chemical composition of the essential oil of $F$. assafoetida aeial parts

\begin{tabular}{|c|c|c|c|}
\hline No. & K. I & Components & Composition (\%) \\
\hline 1 & 1113 & $\alpha$-Pinene & 0.6 \\
\hline 2 & 1175 & 2-(Bromomethyl)trimethylcyclohexene & 1.7 \\
\hline 3 & 1177 & trimethyl-4-methylidene-cyclohexene & 0.2 \\
\hline 4 & 1179 & Bicyclo[3.1.1] heptane & 0.3 \\
\hline 5 & 1195 & $\beta$-Myrcene & 0.6 \\
\hline 6 & 1201 & Decane & 0.6 \\
\hline 7 & 1221 & Benzene & 0.3 \\
\hline 8 & 1225 & dl-Limonene & 0.8 \\
\hline 9 & 1235 & Octatriene, 3,7-dimethyl-E, & 0.9 \\
\hline 10 & 1243 & Octatriene, 3,7-dimethyl-,Z & 0.4 \\
\hline 11 & 1289 & Undecane & 0.4 \\
\hline 12 & 1322 & Alloocimene & 0.2 \\
\hline 13 & 1379 & Arsine triethyl & 8.7 \\
\hline 14 & 1382 & Trans propenyl s-butyl disulfide & 0.7 \\
\hline 15 & 1465 & Fenchyl acetate & 4.7 \\
\hline 16 & 1640 & Phenol, 5-methyl-2-(1-methylethyl) & 2.0 \\
\hline 17 & 1663 & Phenol, 2-methyl-5-(1-methylethyl) & 18.2 \\
\hline 18 & 1682 & Cyclohexene,methyl-3-(methylethenyl) & 0.4 \\
\hline 19 & 1708 & $(+)$-2-Carene & 0.6 \\
\hline 20 & 1730 & Carvacryl acetate & 0.2 \\
\hline 21 & 1746 & b-Elemene & 0.3 \\
\hline 22 & 1758 & Benzene, 1,2-dimethoxy-4-(2-propenyl) & 0.2 \\
\hline 23 & 1775 & trans-Caryophyllene 0.3 & \\
\hline 24 & 1778 & Butanoic acid, 3-methyl-, 1-ethenyl-1,5-dimethyl-4-hexenyl ester & 0.1 \\
\hline 25 & 1782 & $\begin{array}{l}\text { 10-Oxatetracyclotetradecane-9,11,14-trione 4- } \\
\text { [(2-methoxyethoxy)methoxy]-5-methyl }\end{array}$ & 0.2 \\
\hline 26 & 1788 & ß.-Elemene & 0.3 \\
\hline 27 & 1799 & $\beta$-Selinene & 0.8 \\
\hline 28 & 1802 & Camphene & 1.2 \\
\hline 29 & 1806 & 1H-Cyclopropa[a]naphthalene, decahydro-trimethyl-7-methylene- & 0.3 \\
\hline 30 & 1811 & Dodecatriene-dimethyl-3-methylene- & 0.9 \\
\hline 31 & 1821 & (+)-Epi-bicyclosesquiphellandrene & 0.4 \\
\hline 32 & 1828 & Cyclohexane, methylene & 0.3 \\
\hline 33 & 1840 & g.-curcumene & 0.3 \\
\hline 34 & 1847 & Spiro[5.5]undec-2-ene,trimethyl-methylene- & 1.9 \\
\hline 35 & 1850 & b-Selinene & 0.4 \\
\hline 36 & 1856 & Lepidozene & 0.7 \\
\hline 37 & 1859 & Valencene & 0.7 \\
\hline 38 & 1969 & Albicanol & 2.5 \\
\hline 39 & 1876 & b.-Bisabolene & 1.3 \\
\hline 40 & 1884 & Naphthalene, octahydro-7-methyl-4-methylene-1-(1-methylethyl)- & 0.4 \\
\hline 41 & 1897 & Benzodioxole, methoxy-6-(propenyl) 4.4 & \\
\hline 42 & 1914 & Trans-. $\gamma$-- bisabolene & 2.3 \\
\hline 43 & 1925 & Cis- $\alpha .-$ bisabolene & 1.5 \\
\hline 44 & 1933 & Spirobi(4-phenyl-3H-oxathiazoline & 0.8 \\
\hline 45 & 1938 & Elemol & 0.4 \\
\hline 46 & 1942 & Benzene, trimethoxy-5-(2-propenyl) & 0.5 \\
\hline 47 & 1949 & Methano-1-benzoxepin, octahydro tetramethyl & 0.6 \\
\hline 48 & 1956 & Dodecatrien-3-ol, trimethyl & 0.5 \\
\hline 49 & 1989 & (2,6-Dimethyl-hepta-1,5-dienyl) -trimethyl-bicyclo[4.2.0]oct- 2-ene & 0.4 \\
\hline 50 & 2021 & Guaiol & 1.7 \\
\hline 51 & 2038 & 2-naphthalenemethanol -octahydro-. tetramethyl- & 1.3 \\
\hline 52 & 2072 & Cyclopropa[a]naphthalene-octahydro-tetramethyl- & 6.6 \\
\hline 53 & 2087 & Selina-4(19),11-DIENE & 0.6 \\
\hline 54 & 2101 & Naphthalene,octahydro-dimethyl-7-(1-methylethenyl) & 1.6 \\
\hline 55 & 2123 & Neoisolongifolene & 2.2 \\
\hline 56 & 2136 & 2-Naphthalenemethanol, octahydro-8-tetramethyl & 0.7 \\
\hline 57 & 2145 & Naphthalene, octahydro-7-methyl-4-methylene-1-(1-methylethyl)-, & 2.4 \\
\hline 58 & 2157 & Naphthalene, octahydro-4a,8-dimethyl-2-(1-methylethylidene) & 0.6 \\
\hline 59 & 2206 & $\gamma$-Gurjunene & 2.3 \\
\hline 60 & 2215 & Azulene, octahydr1,4-dimethyl-7-(1-methylethenyl) & 3.0 \\
\hline 61 & 2242 & $\alpha .-B i s a b o l o l$ & 10.4 \\
\hline total & & & 98.8 \\
\hline
\end{tabular}




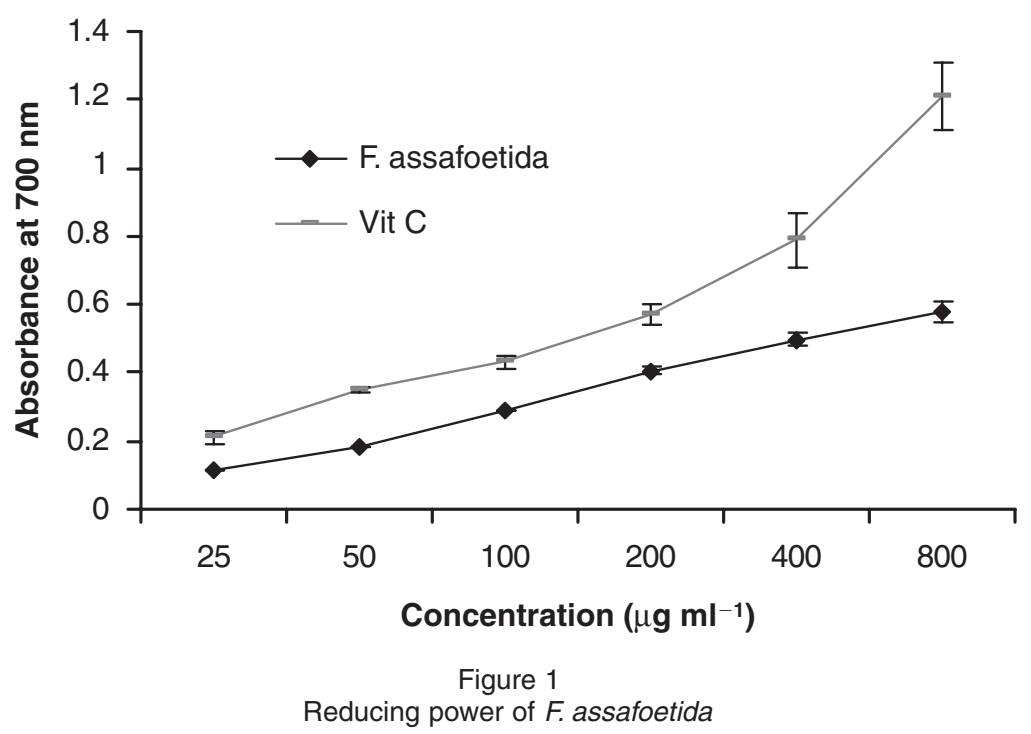

assafoetida. It was found that the reducing powers of the extracts also increased with anincrease in their concentrations. The extract exhibited a fairy weak reducing power at 25 and $800 \mu \mathrm{g} \mathrm{ml}^{-1}$ which was not comparable with Vit $C(p<0.001)$.

\subsection{Assay of nitric oxide-scavenging activity}

The extracts also showed weak nitric oxidescavenging activity between 0.1 and $800 \mathrm{mg} \mathrm{ml}^{-1}$. The \% inhibition increased with increasing concentration of the extract. $\mathrm{IC}_{50}$ was $270 \pm 3$ for F. assafoetida vs. $17.01 \pm 0.03 \mathrm{mg} \mathrm{ml}^{-1}$ for quercetin.

\section{6. $\mathrm{Fe}^{2+}$ chelating activity of extract}

The absorbance of $\mathrm{Fe}^{2+}$-ferrozine complex decreased dose-dependently, i.e. the activity increased with increasing concentration from 0.2 to $3.2 \mathrm{mg} \mathrm{ml}^{-1}$. F. assafoetida extract showed good $\mathrm{Fe}^{2+}$ chelating ability. $I_{50}$ was $0.57 \pm 0.02 \mathrm{mg} \mathrm{ml}^{-1}$. EDTA showed very strong activity $\left(\mathrm{IC}_{50}=18 \mathrm{mg} \mathrm{ml}^{-1}\right)$.

\subsection{FTC Method}

Figure 2 shows the time-course plots for the antioxidative activity of the $F$. assafoetida extract using the FTC method. The peroxidation inhibition (antioxidant activity) of the extract exhibited values from $82 \%$ (at $24^{\text {th }}$ hrs) and $88 \%$ (at $72^{\text {nd }}$ hrs). The extracts tested exhibited very low antioxidant activity. There were significant differences between the extracts and controls $(p<0.01)$.

\section{DISCUSSION}

Sixty one compounds were identified in the present study, representing $98.8 \%$ of the total oil. Only 25 compounds have been a identified in recently published paper (Khajeh et al. 2005). E-1propenyl sec-butyl disulfide was the major component of the plants in that report $(40.0 \%)$ but this component was only a minor one in our study $(0.7 \%)$. Phenol, 2-methyl-5-(1-methyl ethyl) with $18.2 \%$ and $\alpha$-Bisabolol with $10.4 \%$ were the major compounds. Maybe local climate and/ or the increase in temperature to $300^{\circ} \mathrm{C}$ (instead of $250^{\circ} \mathrm{C}$ in the Khajeh report) have played a major role in the number of identified components.

Total phenol compound, as determined by the Folin Ciocalteau method, was reported as gallic acid equivalents and total flavonoid content was reported as the quercetin equivalent/g of extract powder by $\mathrm{AlCl} 3$ colorimetric method. This plant showed high total phenol and flavonoid contents. Phenols and polyphenolic compounds, such as flavonoids, are widely found in food products derived from plant sources, and they have been shown to possess significant antioxidant activities (van Acker et al. 1996). Studies have shown that increasing levels of flavonoids in the diet could decrease certain human diseases (Hertog et al. 1993).

The model of scavenging the stable DPPH radical is a widely used method to evaluate the free radical scavenging ability of various samples (Lee et al. 2003). DPPH is a stable nitrogen-centered free radical, the color of which changes from violet to yellow upon reduction by either the process of hydrogen- or electron- donation. Substances which are able to perform this reaction can be considered as antioxidants and therefore radical scavengers (Brand-Williams et al. 1995). It was found that the radical- scavenging activity of the extracts increased with increasing concentration. $\mathrm{IC}_{50}$ for DPPH radical-scavenging activity was $380 \pm 12 \mathrm{mg}$ $\mathrm{ml}^{-1}$. The high total phenol and flavonoid contents of this plant may lead to its good DPPH-scavenging activity.

$\mathrm{Fe}$ (III) reduction is often used as an indicator of electron- donating activity, which is an important 


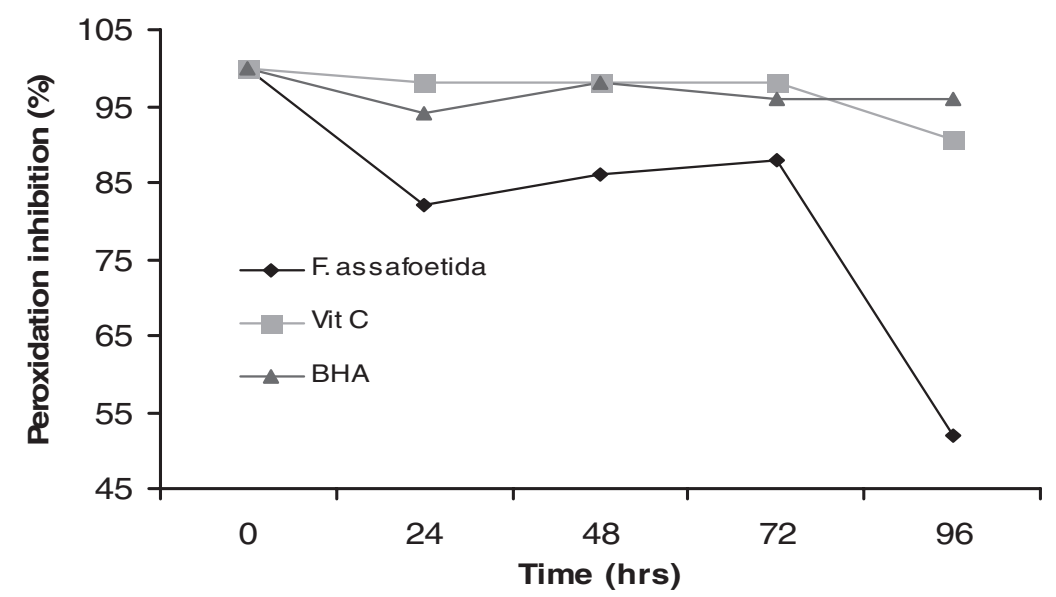

Figure 2

Antioxidant activity of $F$. assafoetida in FTC method at different incubation times. Plant methanolic extract $(0.4 \mathrm{mg} / \mathrm{ml})$, Vit $\mathrm{C}$ and BHA $(0.1 \mathrm{mg} / \mathrm{ml})$.

mechanism of phenolic antioxidant action (Yildirim et al. 2001). In this assay, the presence of reductants (antioxidants) in the samples would result in the reducing of $\mathrm{Fe}^{3+}$ to $\mathrm{Fe}^{2+}$ by donating an electron. Amount of $\mathrm{Fe}^{2+}$ complex can be then be monitored by measuring the formation of Perl's Prussian blue at $700 \mathrm{~nm}$. Increasing absorbance at $700 \mathrm{~nm}$ indicates an increase in reductive ability.

Figure 1 shows the dose- response curves for the reducing powers of the extracts from $F$. assafoetida. The extracts exhibited a fairy weak reducing power at 25 and $800 \mu \mathrm{g} \mathrm{ml}^{-1}$ which was not comparable with Vit $C(p<0.001)$. It was evident that $F$. assafoetida did not show reductive potential and could not serve as electron donors for terminating the radical chain reaction.

The extracts also showed weak nitric oxidescavenging activity between 0.1 and $800 \mathrm{mg} \mathrm{ml}^{-1}$. The procedure is based on the principle that sodium nitroprusside in an aqueous solution at physiological $\mathrm{pH}$ spontaneously generates nitric oxide which interacts with oxygen to produce nitrite ions that can be estimated using Griess reagent. Scavengers of nitric oxide compete with oxygen, leading to reduced production of nitrite ions. The $\%$ inhibition increased with an increasing concentration of the extract. IC $\mathrm{IC}_{50}$ was $270 \pm 3$ for $F$. assafoetida vs. $17.01 \pm 0.03 \mathrm{mg} \mathrm{ml}^{-1}$ for quercetin. In addition to reactive oxygen species, nitric oxide is also implicated in inflammation, cancer and other pathological conditions (Moncada et al. 1991). The plant/plant products may have the property to counteract the effect of NO formation and in turn may be of considerable interest in preventing the ill effects of excessive NO generation in the human body. Furthermore, the scavenging activity may also help to arrest the chain of reactions initiated by excess generation of $\mathrm{NO}$ that are detrimental to human health.

Iron chelators mobilize tissue iron by forming soluble, stable complexes that are then excreted in the feces and/or urine. Chelation therapy reduces iron-related complications in humans and thereby improves quality of life and overall survival of some diseases such as Thalassemia major (Hebbel et al. 1990). In addition, brain iron dysregulation and its association with amyloid precursor protein plaque formation are implicated in Alzheimer's disease (AD) pathology and so iron chelation could be considered a rational therapeutic strategy for $A D$ (Reznichenko et al. 2006). Foods are often contaminated with transition metal ions which may be introduced by processing methods. Bivalent transition metal ions play an important role as catalysts in oxidative processes, leading to the formation of hydroxyl radicals and hydroperoxide decomposition reactions via Fenton chemistry (Halliwell 1997). These processes can be delayed by iron chelation and deactivation. The transition metal, iron, is capable of generating free radicals from peroxides by Fenton reactions and may be implicated in human cardiovascular disease (Ebrahimzadeh et al. 2008c; Nabavi et al. 2008b). Because $\mathrm{Fe}^{2+}$ also has been shown to cause the production of oxyradicals and lipid peroxidation, minimizing $\mathrm{Fe}^{2+}$ concentration in Fenton reactions affords protection against oxidative damage. The chelating of ferrous ions by the extract was estimated by the method of Dinis et al., (Ebrahimzadeh et al. 2008 a,b,c; Nabavi et al. 2008a). Ferrozine can quantitatively form complexes with $\mathrm{Fe}^{2+}$. In the presence of other chelating agents, the complex formation is disrupted with the result that the red color of the complexes decreases. In this assay, both extract and EDTA interfered with the formation of ferrous and ferrozine complex, suggesting that it has chelating activity and captures ferrous ion before ferrozine. The absorbance of $\mathrm{Fe}^{2+}$ - ferrozine complex decreased dose-dependently, i.e. the activity increased with the increasing concentration from 0.2 to $3.2 \mathrm{mg} \mathrm{ml}^{-1}$. Metal chelating capacity was significant since the extract reduced the concentration of the catalyzing transition metal in lipid peroxidation (Duh et al. 1999). It was reported that chelating agents are effective as secondary 
antioxidants because they reduce the redox potential, thereby stabilizing the oxidized form of the metal ion (Gordon 1990). F. assafoetida extract showed good $\mathrm{Fe}^{2+}$ chelating ability. $\mathrm{IC}_{50}$ was $0.57 \pm$ $0.02 \mathrm{mg} \mathrm{ml}^{-1}$.

Figure 2 shows the time-course plots for the antioxidative activity of the $F$. assafoetida extract using the FTC method. Membrane lipids are rich in unsaturated fatty acids which are most susceptible to oxidative processes. Specially, linoleic acid and arachidonic acid are targets of lipid peroxidation ( $\mathrm{Yu}$ 2001). The inhibition of lipid peroxidation by antioxidants may be due to their free radicalscavenging activities. Superoxide indirectly initiates lipid peroxidation because superoxide anion acts as a precursor of singlet oxygen and hydroxyl radical (Nabavi et al. 2008a). Hydroxyl radicals eliminate hydrogen atoms from the membrane lipids, which results in lipid peroxidation. The tested extracts exhibited very low antioxidant activity. There were significant differences between extracts and controls $(p<0.01)$.

Be complete but concise in discussing findings, comparing results with previous work and proposing explanations for the results observed. Avoid speculation unsupported by the data obtained. Concluding statements may be either incorporated at the end of this section or under a separate Conclusions section. Citations should be according to the described above.

\section{CONCLUSIONS}

The aerial parts of the extract of $F$. assafoetida exhibited good but different levels of antioxidant activity in all the models studied. The extracts had good $\mathrm{Fe}^{2+}$ chelating ability, DPPH radical and nitric oxide scavenging activity. Further investigation of individual compounds, their in vivo antioxidant activities and in different antioxidant mechanisms is needed.

\section{ACKNOWLEDGMENTS}

This research was supported by a grant from the research council of Mazandaran University of Medical Sciences and Islamic Azad University of Qaemshahr.

\section{REFERENCES}

Abd El-Razek MH, Ohta S, Ahmed AA, Hirata T. 2001. Sesquiterpene coumarins from the roots of Ferula asafetida. Phytochem. 58, 1289-1295.

Brand-Williams W, Cuvelier M, Berset C. 1995. Use of a free radical method to evaluate antioxidant activity. Food Sci. Technol. 28, 25-30.

Cao GH, Sofic E, Prior RL. 1996. Antioxidant capacity of tea and vegetables. J. Agri. Food Chem. 44, 3426-3431.
Duh PD, Tu YY, Yen GC. 1999. Antioxidant activity of water extract of harng Jyur (Chrysanthemum morifolium Ramat). Lebensm Wiss Technol. 32, 269-277.

Ebrahimzadeh MA, Hosseinimehr SJ, Hamidinia A, Jafari M. 2008a. Antioxidant and free radical scavenging activity of Feijoa sallowiana fruits peel and leaves. Pharmacologyonline 1, 7-14.

Ebrahimzadeh MA, Pourmorad F, Hafezi S. 2008b. Antioxidant Activities of Iranian Corn Silk. Turk. J. Biol. 32, 43-49.

Ebrahimzadeh MA, Pourmorad F, Bekhradnia AR. 2008c. Iron chelating activity screening, phenol and flavonoid content of some medicinal plants from Iran. Afr. J. of Biotech. 7 (18), 3188-3192.

Eigner D, Scholz D. 1990. Das Zauberbchlein der Gyani Dolma. Pharmazie in userer Zeit. 19, 141-152.

Fatehi M, Farifteh F, Fatehi-Hassanabad Z. 2004. Antispasmodic and hypotensive effects of Ferula asafoetida gum extract. Journal of Ethnopharmacol. 91, 321-324.

Fernch D. 1971. Ethnobothany of the Umbelliferae. in Heywood. VH, ed., The Chemistry and Biology of the Umberifella. Academic press, London. pp. 285-412.

Gordon MH. 1990. The mechanism of antioxidant action in vitro. in Hudson BJF, ed. Food antioxidants. Elsevier Applied Science, London. pp. 1-18.

Hebbel RP, Leung A, Mohandas N. 1990. Oxidationinduced changes in microheological properties of the red cell membrane. Blood 76, 1015-1022.

Halliwell B. 1997. Antioxidants: the basics- what they are and how to evaluate them. Adv Pharmacol. 38, 3-20.

Halliwell B, Gutteridge JMC, Cross CE. 1992. Free radicals, antioxidants and human disease: where are we now? J. Lab. Clin. Med. 119, 598-620.

Hertog MLG., Feskens EJM., Hollman PHC., Katan MB, Kromhout D. 1993. Dietary antioxidants flavonoids and the risk of coronary heart disease: the zutphen elderly study. Lancet 342, 1007-1011.

Keshri G, Bajpai M, Lakshmi V, Sreenivasulu Setty B, Gupta G. 2004. Role of energy metabolism in the pregnancy interceptive action of Ferula assafoetida and Melia azedarach extracts in rat, Contraception 70, 429- 432.

Khajeh M, Yamini Y, Bahramifar N, Sefidkon F, Pirmoradei MR. 2005. Comparison of essential oils compositions of Ferula assa-foetida obtained by supercritical carbon dioxide extraction and hydrodistillation methods Food Chem. 91, 639-644.

Kojima K, Isaka K, Ondognii $\mathrm{P}$, Zevgeegiino $\mathrm{O}$, Gombosurengyin P, Davgiin K, et al., 2000. Sesquiterpenoid derivatives from Ferula ferulioids IV. Chem Pharm Bull. 48, 353-356.

Lee SE, Hwang HJ, Ha JS, Jeong HS, Kim JH. 2003. Screening of medicinal plant extracts for antioxidant activity. Life Sci. 73, 167-179.

Leung AY. 1980. Encyclopedia of Common Natural Ingredients used in Food, Drugs and Cosmetics. Wiley, New York.

Moncada A, Palmer RMJ, Higgs EA. 1991. Nitric oxide: physiology, pathophysiology and pharmacology. Pharmacol Rev. 43, 109-142.

Nabavi SM, Ebrahimzadeh MA, Nabavi SF, Hamidinia A, Bekhradnia AR. 2008a. Determination of antioxidant activity, phenol and flavonoids content of Parrotia persica Mey. Pharmacologyonline 2, 560-567.

Nabavi SM, Ebrahimzadeh MA, Nabavi SF, Jafari M. 2008b. Free radical scavenging activity and antioxidant capacity of Eryngium caucasicum Trautv and Froripia subpinata. Pharmacologyonline 3, 19-25. 
Reznichenko L, Amit T, Zheng H, Avramovich-Tirosh Y, Youdim MBH, Weinreb O, Mandel S. 2006. Reduction of iron-regulated amyloid precursor protein and [beta]-amyloid peptide by (-)-epigallocatechin-3gallate in cell cultures: implications for iron chelation in Alzheimer's disease. J. Neurochem. 97 (2), 527536.

Su BN, Takaishi Y, Honda G, Itoh M, Takeda Y, Kodzhimatov OK, et al. 2000. Sesquiterpene phenylpropanoid and sesquiterpene chromone derivatives from Ferula pallida. J. Nat. Prod. 63, 520-522.

Van Acker SABE, van Den Berg DJ, Tromp MNJL, Griffioen DH, Van Bennekom WP, van der Vijgh WJF, et al. 1996. Structural aspects of antioxidant activity of flavanoids. Free Radical Bio Med. 20 (3), 331-342.
Wang H, Cao GH, Prior RL. 1996. Total antioxidant capacity of fruits. J. Agr. Food Chem. 44, 701-705.

Yildirim A, Mavi A, Kara A. 2001. Determination of antioxidant and antimicrobial activities of Rumex crispus L. extracts. J. Agr. Food Chem. 49, 4083-4089.

Yu LL. 2001. Free radical scavenging properties of conjugated linoleic acids. J. Agr. Food Chem. 49 (7), 3452-3456.

Zheng W, Wang S. 2001. Antioxidant activity and phenolic composition in selected herbs. J. Agr. Food Chem. 49, 5165-5170.

Recibido: 7/1/09

Aceptado: 9/3/09 